Ambient Science, 2016: Vol. 03(Sp1); 32-34

DOI:10.21276/ambi.2016.03.sp1.ra03

ambient

SCIENCE

Vol. 3(Sp1):32-34

Year 2016

Research ARTICLE

\title{
Relationship Between Job Characteristics Model and Learning Organization: A Case Study of a Ceramic and Tile Company of Maybod City, Iran
}

\section{Maryam Yazdanfar*, Marjan Mohammad Jafari}

Department of Industrial Engineering, Department of Kerman, Islamic Azad University, Kerman, Iran

Study Area: Meybod City, Iran

Coordinate: $32^{\circ} 15^{\prime} \mathrm{N} ; 54^{\circ} \mathrm{or}$ 'E

Key words: Knowledge trasfer, Job record, Job performence

\begin{abstract}
Learning organisations are always seen to be adjustable in its behaviour so that it promotes new knowledge and ideas. According to job characteristic theory, when the staff feel that their job is valuable and see the feedback of their performance, they would obtain enough motivation for doing their tasks more perfectly. The main aim of the present research is to study the relationship between job characteristic model adopted in a learning organisation where 147 staff were selected as a subject by using random sampling and Cochran's formula. A set of questionnaire was distributed to collect research data. Statistical software SPSS 16.00 was used to analyse the obtained data from descriptive - inferential statistical methods. The results showed that there is a positive and significant relationship between job characteristic and learning organisation at the significant level of $95 \%$ which strengthened the main hypothesis of the research. Further, there a positive and significant relationship between all aspects of job characteristic and learning organization is also witnessed. The positive and signif icant relationship between adjusting variables; level of education, type of job and main variables are also a part of our finding. There is no significant relationship between gender, job record and other variables revealed.
\end{abstract}

(2004) reported a significant correlation between main aspects of staff jobs (including; skill variety, task identity, independence, task importance and job feedback) with its resulted in mental and emotional conditions (including; job concept, responsibility toward results of job awareness). Rahimi (2005) reported a direct and significant relationship between potential job motivation and job satisfaction, knowledge variety and job skill, job identity and job importance, job independence, job feedback and job satisfaction. Further, Davis (2005) a significant relationship between financial performance and knowledge of the organisation and between returned invested amount and learning organisation. Reports also available which reveal that the rate of interest and income of company owners increase by considering an organisation as learning organization (Azeem, 2010). Birdthistle \& Fleming (2005) reported a significant difference between the size of family commercial 
organisations in creating continuous learning opportunities at individual level, while there was no significant difference between the groups and discussion aspect about learning while conducting the study in Ireland. Also, there was no signif icant difference between the groups and team learning and cooperation. (Voon et al., 2011).

By keeping in mind the above all results the present research was an attempt to study the different aspects of job characteristics model and learning organisation model at ceramic and tile Golchin company and the relationship between two mentioned models.

\section{Methodology:}

Present research is of a descriptive- survey type where a statistical community which includes all the staff members of Golchinceramic and tile company of Maybod city at the year 2015. Among 597 people total 147 staff were selected as subjects by using random sampling method.The main aim of this research was to study the relationship between job characteristics and learning organisation at Golchinceramic and tile company of Maybod city. Following the main research hypothesis, we tried to confirm whether any significant relationship exists between these two variables which have been tried to conf irm on the basis of the conceptual developed model and other secondary hypotheses.

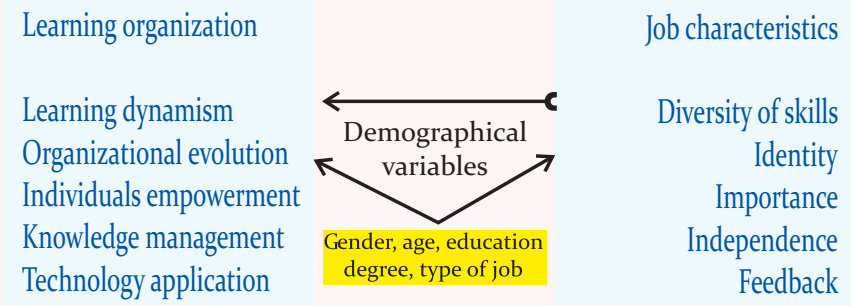

Figure-1: Research conceptual model

\section{Results and Discussion:}

In this study, $12.5 \%$ of respondents were women whereas $78.5 \%$ were men. Other demographic information are in table-1.

As per the results of descriptive statistics, the means of different dimensions of job characteristics are 2.6901, $2.8457,2.9824,2.7676$ and 2.6797 for skill variety, job identity, job importance, independence and feedback, respectively. The results of the mean for aspects of job characteristics show the highest mean belongs to job importance. Thus, it could be said that jobs are important for staff and they need different skills for doing their tasks. But, feedback aspect revealed lowest mean which shows that the feedback and evaluating systems did not evaluate the performance of staff regularly and actively (table 2 ).
Table-1: The frequency of independent variables of statistical community of the study.

\begin{tabular}{lllll}
\hline Sum & \multicolumn{2}{c}{$\begin{array}{l}\text { Relative } \\
\text { frequency frequency }\end{array}$} & \multicolumn{2}{c}{ Situation } \\
\hline $100 \%$ & $12.50 \%$ & 16 & Female & Gender \\
& $87.50 \%$ & 112 & Male & Education \\
\hline $100 \%$ & $10.90 \%$ & 14 & Diploma & level \\
& $22.70 \%$ & 29 & Associate degree & \\
& $53.10 \%$ & 67 & BA & Job record \\
& $13 \cdot 30 \%$ & 17 & MA & \\
\hline $100 \%$ & $19-\mathrm{May}$ & 25 & Less than 5 years & \\
& $20-\mathrm{Mar}$ & 26 & Between 6-11 yrs. & \\
& $14-\mathrm{Jan}$ & 81 & Between 11-15 yrs. & \\
& $17-\mathrm{Feb}$ & 22 & Between 16-20 yrs. & \\
& $17-\mathrm{Feb}$ & 22 & Between 21-25 yrs. & \\
& $11-\mathrm{Jul}$ & 15 & Between 26-30 years & \\
\hline $100 \%$ & $53.90 \%$ & 69 & Technical/operation & Type of \\
& $15.60 \%$ & 20 & Services & job \\
& $20.30 \%$ & 26 & Financial/ & \\
& & & administrative & \\
& $10.20 \%$ & 13 & Army staff & \\
\hline
\end{tabular}

Table 2.The scores of learning organization and job characteristics and their spectra for the sample

\begin{tabular}{|c|c|c|c|c|c|}
\hline $\begin{array}{l}\text { Standard } \\
\text { deviation }\end{array}$ & Mean & Maxi. & Min. & Num. & Spectrum \\
\hline $68358 / o$ & $6840 / 2$ & $33 / 4$ & 1 & 128 & Learning dynamism \\
\hline $69332 / 0$ & $7703 / 2$ & 4-Mar & 1-Mar & 128 & $\begin{array}{l}\text { Organizational } \\
\text { evolution }\end{array}$ \\
\hline $75525 / 0$ & $8563 / 2$ & 5 & 1 & 128 & $\begin{array}{l}\text { Individuals } \\
\text { empowerment }\end{array}$ \\
\hline $65987 / 0$ & $6781 / 2$ & 4-Aug & 1-Feb & 128 & $\begin{array}{l}\text { Knowledge } \\
\text { management }\end{array}$ \\
\hline $66952 / o$ & $6023 / 2$ & 4-May & 1 & 128 & Using technology \\
\hline $60621 / 0$ & $7185 / 2$ & $29 / 4$ & 1 & 128 & $\begin{array}{l}\text { Learning } \\
\text { organization }\end{array}$ \\
\hline $5173 / 0$ & $6901 / 2$ & 4 & $17 / 1$ & 128 & Diversity of skills \\
\hline $61086 / 0$ & $8457 / 2$ & 1 & $75 / 4$ & 128 & Job identity \\
\hline $53718 / 0$ & $9824 / 2$ & 1-May & $25 / 4$ & 128 & Job importance \\
\hline $6028 / 0$ & $7676 / 2$ & 1 & 4 & 128 & Independence \\
\hline $62107 / 0$ & $6797 / 2$ & 1 & 4-Apr & 128 & Feedback \\
\hline $3963 / 0$ & $7792 / 2$ & 1-Mar & $78 / 3$ & 128 & Job characteristics \\
\hline
\end{tabular}

As we mentioned, the main hypothesis in the present study states there is signif icant relationship exist between job characteristics and learning organization. Thus, the result revealed that Pearson's correlation coefficient (PCC) is equal to 0.432 for these two variables and hypothesis is confirmed at confidence level of $99 \%$ (Table-3a).Thus, the job characteristics model is considered as variable to guide this organization (Maybod ceramic and tile company) toward learning organization. As a result, we can have learning organisation by establishing job characteristics in ceramic and tile company, redesign jobs and creating motivational jobs.

PCC is equal to 0.342 for two variables; diversity of skills and learning organisation. Thus, the first secondary 
Research ARTICLE

hypothesis is conf irmed (Table-3b). The diversity of skills means using knowledge and different skills for doing tasks. When individuals have high motivation for doing their tasks, they try to use different technologies to reach learning organisation and improve organisational processes. If increasing staffs' skills be an element of organisation's strategy in ceramic and tile company, since human resource includes experts who received information, it is valuable knowledge for personal and organisational applications. It causes that individual can obtain enough resources for doing their tasks and effective using of resources. Thus, continuous learning, using different technologies for improving organisational processes will be led to a learning organisation.

PCC is equal to 0.213 for two variables; job identity and learning organisation in Golchin ceramic and tile company of Maybod (Table-3c). Thus, the second secondary hypothesis is confirmed. Job identity can guide the organization toward learning organisation through resulted advantages from doing tasks by staff, completely. Identity means doing a task by staff, completely. When staff do their tasks at the mentioned company, completely.

PCC is equal to 0.249 for two variables; job importance and learning organisation (Table-3d). Thus, the third secondary hypothesis of this research is confirmed. It means that job designing and being an important job in view of staff and people outside of the organization would be led to increasing internal job motivation.

PCC is equal to 0.225 for two variables; job independence and learning organisation (Table-ze). Thus, the fourth secondary hypothesis is confirmed. Job independence means freedom in doing tasks. Regarding that independence, aspect leads to responsibility as mental result of doing tasks. Thus, it is necessary to learn at the organisation. Staff are responsible for their learning and others. They found a relationship between their responsibilities and organisation, $\mathrm{s}$ goals as a whole and they try to have learning organization. Thus, reinforcement of this aspect can change the organization and guide it toward learning organisation.

PCC is equal to 0.378 for two variables; feedback and learning organisation (Table-3f). Thus, the fifth secondary hypothesis of this research is confirmed. Feedback and evaluating systems at mentioned company evaluate and control staff and their performance, actively.

Table-za to f: Results of Pearsons' correlation coefficient Tests

\begin{tabular}{|c|c|c|c|c|}
\hline Tab & $\begin{array}{l}\text { Index } \\
\text { variables }\end{array}$ & Number & $\begin{array}{l}\text { Significant } \\
\text { level }\end{array}$ & $\begin{array}{l}\text { Correlation } \\
\text { coefficient }\end{array}$ \\
\hline $3 a$ & $\begin{array}{l}\text { Job characteristics \& } \\
\text { learning organization }\end{array}$ & 128 & $<0.000$ & 0.432 \\
\hline $3 b$ & $\begin{array}{l}\text { Diversity of skills \& } \\
\text { learning organization }\end{array}$ & 128 & $<0.000$ & 0.342 \\
\hline
\end{tabular}

\begin{tabular}{clccc} 
3c & $\begin{array}{l}\text { Job identity \& } \\
\text { learning organization }\end{array}$ & 128 & $<0.016$ & 0.213 \\
3d & $\begin{array}{l}\text { Job importance \& } \\
\text { learning organization }\end{array}$ & 128 & $<0.000$ & 0.249 \\
3e & $\begin{array}{l}\text { Job independence \& } \\
\text { learning organization }\end{array}$ & 128 & $<0.005$ & 0.225 \\
3f & $\begin{array}{l}\text { Job feedback \& } \\
\text { learning organization }\end{array}$ & 128 & $<0.000$ & 0.378 \\
\hline
\end{tabular}

In this study, we studied the relationship between mentioned demographical characteristics, job characteristics and learning organisation separately to verify the hypothesis which reveals there is a significant relationship between job characteristics and demographical characteristics of the studied individuals (including; gender, education level, job record). Finally, we found that there is no signif icant difference between men and women's view and gender does not effect on creating job characteristics and learning organisation. Another result of this research revealed that the individuals with different education levels had different mean values for the learning organisation.

Acknowledgements:

We thank the staffs of the GolchinCeramic and Tile Company for their kind participations.

\section{References:}

Azeem, S.A. (2010): Personality hardiness, job involvement and job burnout among teachers. Int.J.Voc. Tech. Edu., (3):36-40.

Birdthistle, N. \& Fleming, P. (2005): Creating a learning organisation within the family business: an Irish perspective. L. Eur. Ind.Train., 29 (9):730 - 750.

Davis, D. (2005): The learning organization and it dimensions as key factors infirm performance. Ph.D. Dissertation, University of Wisconsin Milwaukee.

Goh, S.C. (1998): Toward a learning organizations: The strategic Building Blocks. S.A.M.Adv. Manag. J., 63(2):315-326.

Jamshidian, M. \& Takht-Tavoos, M.R. (2004): Increasing intrinsic motivation and job satisfaction. J. Edu. Res. Isfahan Uni. 1(4):30-110.

Khashoee, P. (2003) Staffs' job satisfaction of the finance ministry. MA thesis. Education \& psychology, Tehran university.

Mozafari, P., Valizadeh, J. \& Karimi, H. (2016): Performance Evaluation and Prioritization of Insurance Companies Using the BSC and QFD Hybrid Model. Innov. Res. Eng. Sci., 2(3):32-42

Rahimi A, (2005): The relationship between job characteristics (based on Hackman-Oldham model) with job satisfaction of employees in Electricity Distribution Company South West of Tehran. Xth Conference of Power Distribution Networks, Tehran (Persian).

Voon, M.L., Lo, M.C. , Ngui , K.S. and Ayob, N.B., (2011): The influence of leadership styles on employees' job satisfaction in public sector organizations in Malaysia. Int. J. Bus., Manag. Soc. Sci., 2(1):24-32. 